\title{
Endoscopic ultrasound-guided transjejunal drainage of an obstructed afferent loop using a novel lumen-apposing metal stent
}

A 65-year-old man presented with jaundice, intermittent fever, and abdominal pain for 3 weeks. He had undergone distal gastrectomy with gastrojejunostomy for benign gastric outlet obstruction 40 years previously. His laboratory parameters were as follows: hemoglobin $10.8 \mathrm{~g} / \mathrm{dL}$, total leukocyte count 12700 cells $/ \mathrm{mm}^{3}$, bilirubin $5 \mathrm{mg} / \mathrm{dL}$ (direct $3.6 \mathrm{mg} / \mathrm{dL}$ ), serum albumin $2.5 \mathrm{~g} / \mathrm{dL}$, alkaline phosphatase $568 \mathrm{IU} / \mathrm{L}$ (normal 120 ), and serum lipase $698 \mathrm{U} / \mathrm{L}$ (normal 50). A contrast-enhanced computed tomography (CT) scan of the abdomen showed a grossly dilated afferent limb with dilated common bile duct and pancreatic duct along with peripancreatic fat stranding ( $\triangleright$ Fig. $\mathbf{1}$ ). He received antibiotics along with supportive care. Endoscopic retrograde cholangiopancreatography was not technically feasible because of the surgically altered anatomy. Passage of an endoscope and accessories deep into the afferent loop failed because of the twisted bowel. He therefore

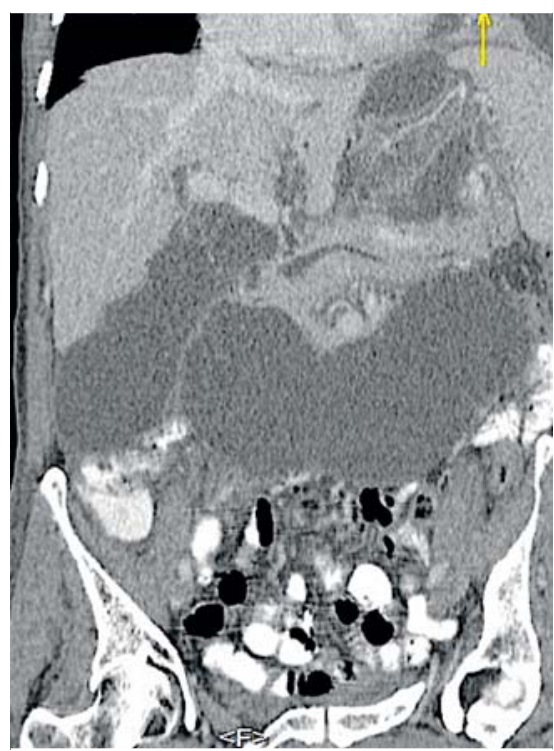

- Fig. 1 Computed tomography image showing the dilated afferent loop, along with dilated common bile duct and pancreatic duct. underwent endoscopic ultrasound (EUS)guided drainage of the afferent limb using a lumen-apposing metal stent (LAMS) ( V Video 1 ).

The dilated afferent loop was best visualized with favorable alignment on EUS from the proximal part of efferent loop, which was punctured with a conventional 19-gauge needle. Injection of contrast

and subsequent passage of a guidewire (0.035 inch, $450 \mathrm{~cm}$, Jagwire; Boston Scientific) through the needle confirmed the afferent jejunal loop ( $\triangleright$ Fig.2a). A balloon ( $4 \mathrm{~mm}$, Titan balloon; Cook Medical) was passed over the guidewire to dilate the fistula track. Finally, the novel LAMS (16-mm diameter, 20-mm long, Spaxus stent; Taewoong-Medical, Korea)

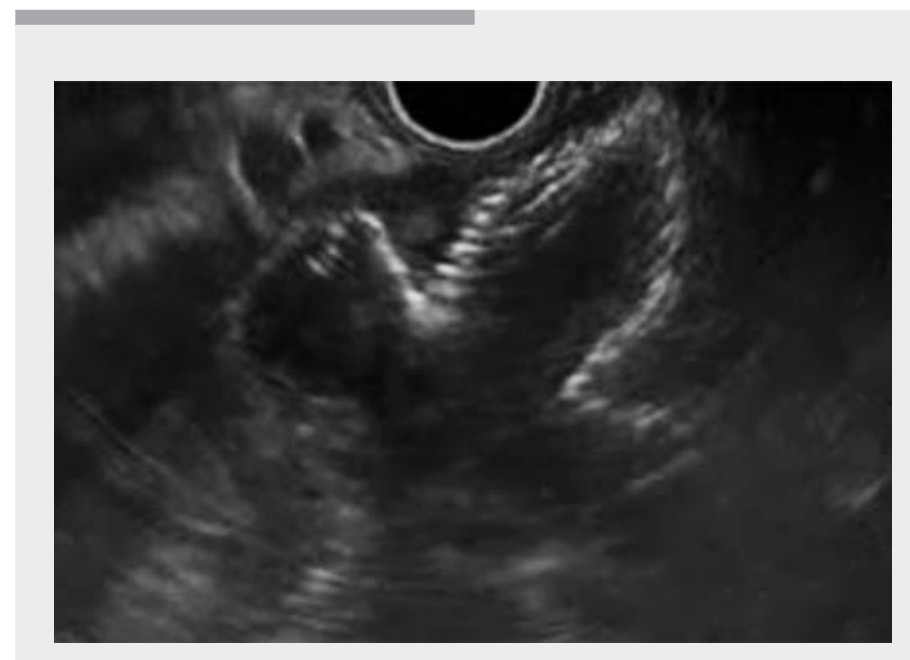

$\checkmark$ Video 1 Video showing endoscopic ultrasound-guided transjejunal drainage of an obstructed afferent loop with a lumen-apposing metal stent.
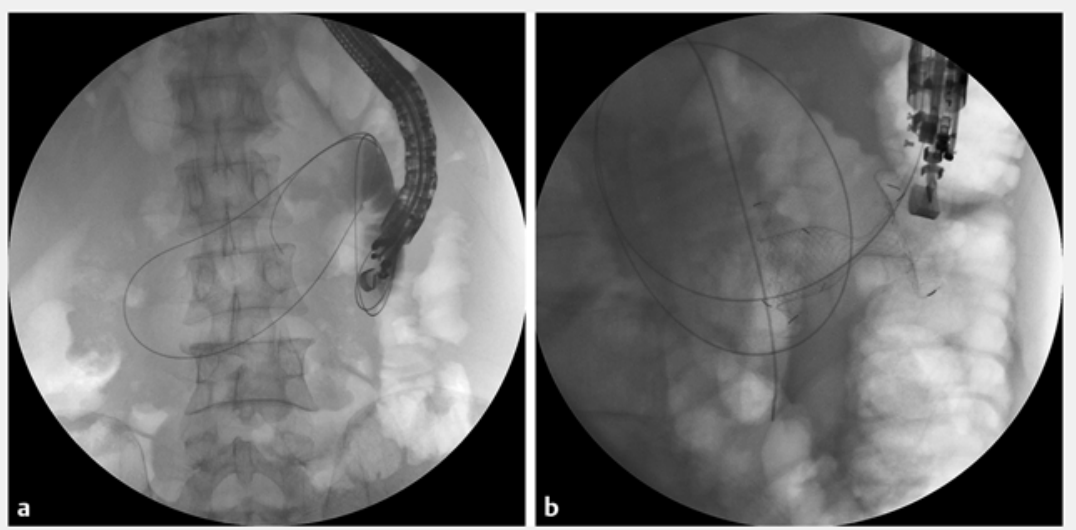

- Fig. 2 Fluoroscopic images showing: a the afferent loop confirmed by contrast injection followed by subsequent coiling of the guidewire; $\mathbf{b}$ transjejunal deployment of a lumen-apposing metal stent under fluoroscopy guidance. 


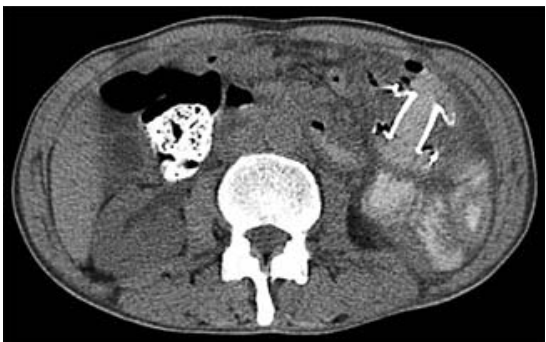

- Fig. 3 Computed tomography image showing the lumen-apposing metal stent in position.

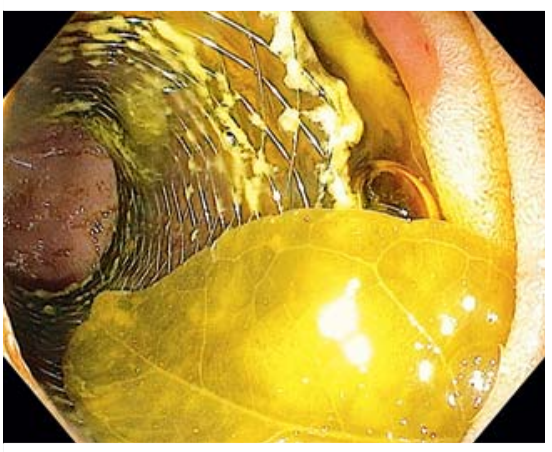

Fig. 4 Follow-up endoscopy at 3 months showing the metal stent in position, with complete drainage of the afferent loop.

was placed across the newly created fistulous track between the afferent and ef-

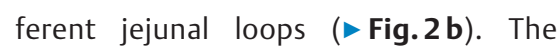
Spaxus is a fully covered LAMS that is available in various diameters with a silicone covering membrane that prevents leaks and tissue in-growth.

There were no periprocedural complications. The patient's symptoms gradually resolved, with improvement in his liver function. A CT scan at 48 hours showed there had been a reduction in the caliber of the afferent loop, the stent was in position, and there was air in the biliary tract ( $\triangleright$ Fig. 3). An upper gastrointestinal endoscopy was performed on day 2 and again 3 months after the procedure; on both occasions, it showed the novel LAMS was correctly positioned ( $>$ Fig. 4 ). So far, the patient has completed 5 months of follow-up and the intention is to remove the LAMS 6 months after the index placement procedure to allow a stable and permanent anastomosis to form between the afferent and efferent jejunal loops. EUS guided trans-jejunal drainage of an obstructed afferent loop using a novel LAMS is feasible and safe in benign conditions.

Afferent loop obstruction is an uncommon complication that occurs years after upper gastrointestinal bypass surgery. A few case reports have demonstrated the feasibility and safety of EUSguided transgastric drainage with a LAMS in afferent loop syndrome associated with upper gastrointestinal malignancy. Though technically challenging, the EUS-guided transjejunal route of drainage of an obstructed afferent loop is safe and feasible.

Endoscopy_UCTN_Code_TTT_1AS_2AD

\section{Competing interests}

\section{None}

The authors

Sundeep Lakhtakia, Radhika Chavan, Jahangeer Basha, Zaheer Nabi, Rajesh Gupta, D. Nageshwar Reddy

Asian Institute of Gastroenterology, Hyderabad, India

\section{Corresponding author}

\section{Radhika Chavan, MD, DNB}

Asian Institute of Gastroenterology, 6-3-661

Somajiguda, Hyderabad 500 082, India

Fax: +91-40-23324255

drradhikachavan@gmail.com

\section{Bibliography}

DOI https://doi.org/10.1055/a-0890-3182

Published online: 9.5.2019

Endoscopy 2019; 51: E253-E254

(C) Georg Thieme Verlag KG

Stuttgart · New York

ISSN 0013-726X

\section{ENDOSCOPY E-VIDEOS \\ https://eref.thieme.de/e-videos}

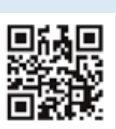

Endoscopy E-Videos is a free access online section, reporting on interesting cases and new techniques in gastroenterological endoscopy. All papers include a high quality video and all contributions are freely accessible online.

This section has its own submission website at https://mc.manuscriptcentral.com/e-videos 